\title{
TOGETHER ON THE PLATFORM
}

\section{Common Action and Reviving the Central Open Public Space in Ruski Car (Russian Tsar) in Ljubljana}

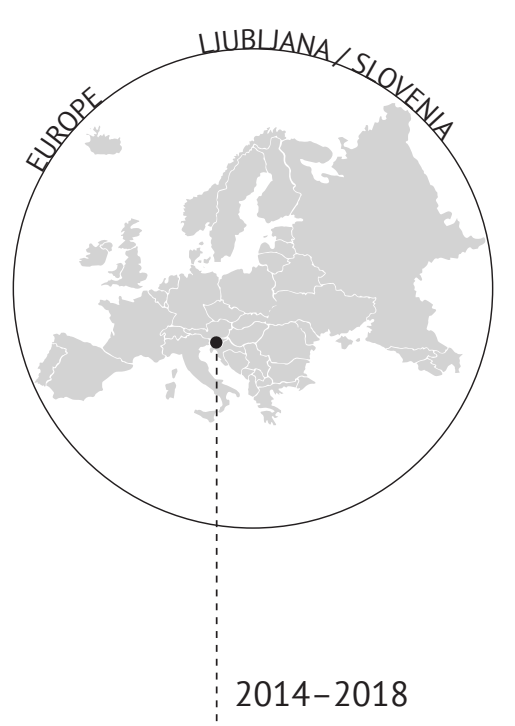

Organisations + Collaborators
Urban Planning Institute of the
Republic of Slovenia (UIRS)
NGO Skupaj na ploščad!
Museum of architecture \& design
Primary school Danila Kumar
University of Ljubljana, Faculty
of Architecture, Department of
Urban Planning
AESOP Thematic group Public
spaces and urban cultures
City of Ljubljana, District office
Posavje
Creative Europe network Human
Cities

\section{Introduction}

Human Cities is a European project. It was set up in 2008 as Human Cities 1 under the European Commission's Creative Europe 2007-2013 programme and has had transdisciplinarity embedded in its core from the very beginning (www.humancities.eu). It addresses issues of urban public space and promotes creative interventions and collaborations between architects, urban planners, sociologists, artists, designers, writers, philosophers and landscape architects, as well as citizens and people who use public space that do not have any professional affiliation to the project (Coirier, Goličnik Marušić, \& Nikšič, 2010). Its main aim is to shed light on new, innovative approaches to urban public open space design and to challenge established practices within the so-called "spatial professions," such as architecture and urban planning.

Human Cities provides 50\% of financial funds for all activities, while the rest must be provided by partners' contributions. Initially, it had been running in four European cities: Brussels, Glasgow,

FIGURE II.9.1 The kick-off meeting between the residents and the professionals in a form of a residentsled walk was organised to start the cooperation. Photo by Blaž Jamšek / UIRS photo archive Human Cities Ljubljana. 
Ljubljana and Milan. It was then prolonged for two more periods to Human Cities 2, which ran from 2010 to 2012, and Human Cities 3, which ran from 2014 to 2018 with a broadened European network including partners from Belgrade, Bilbao, Brussels, Cieszyn, Graz, Helsinki, Ljubljana, London, Milan, St. Etienne and Tallinn.

The project raises awareness for the need for a dynamic, inclusive and systematic approach to the less obvious components of public spaces, such as social networks, behavioural patterns and perceptual dimensions, as part of an endeavour to provide better and more inclusive urban public spaces.

There was a clear understanding from the very beginning of the project that such endeavours could only be successful if cooperation between institutions and professionals from different backgrounds, on the one hand, and the citizens, on the other, were to be established. The initial international team was therefore set up by institutions of different backgrounds in order to provide pluralistic insights into the issue from the very start of the project, and has grown throughout the development of the project from Human Cities 1 to Human Cities 3.

The second round of the project (Human Cities 2) sought to address the gap between urban practice and theory (Houlstan-Hasaerts, Tominc, Nikšič, \& Goličnik Marušić, 2012) and therefore for the first time started to cooperate with other associations on a global scale also. One of them was the Association of European Schools of Planning (AESOP) and its thematic group Public Spaces and Urban Cultures, which tackles issues of urban public spaces via a transdisciplinary approach through scientific, artistic and educational aspects in order to make the gap between theory and practice smaller (http://www.aesop-planning.eu/).

The new theoretical insights from Human Cities 2 helped to frame the agenda of the third round of the project (Human Cities 3), which ran from 2014 to 2018. It is important to note that ever since 2008, which was the official starting point of Human Cities activities, the network grew considerably and new partners with additional critical expertise joined.

Each of the project partners from the collaborating cities had an opportunity to extend its local team and expertise considerably by inviting additional local partners in every city in accordance to their needs and concrete local goals. This flexibility in setting up and continuing to develop the local project teams while also benefiting from the support of the international network proved to be one of the crucial enabling factors for the success of the project.

It is important to highlight that the pan-European framework of the Human Cities project served only as a basic model and common language for the activities across Europe. There was a high level of independence in setting up the local agenda of each of the partnering cities, as long as they were following the basic principles and frame of Human Cities. Each partner had the right and responsibility to set up its local agenda in a co-creation process with any number of relevant local stakeholders. These are discussed later; this was one of the main strengths of the project.

\section{Human Cities 3: Professionals and Residents Working Together for Better Public Space}

To address the question of co-design of public space and to estimate the value of interdisciplinary support to urban civil initiatives, the framework of Human Cities 3 is most relevant. Human Cities 3 defined a set of three main goals to be reached by the international partnership:

1. To review state-of-the-art civil initiatives throughout Europe that are reclaiming public spaces in cities. The review had three main steps: it mapped, analysed and synthesised the gathered data. An international interdisciplinary team of sociologists, architects, designers and urban 
planners worked on the topic and valuable insights emerged out of the research - such as who the most common initiators of bottom-up initiatives for public space improvements were and their socio-economic characteristics. Also, what were the triggers and motivations of their activities, and what are the characteristics of people who support or actively join such initiatives? How do initiatives organise themselves and how do they run their activities, etc.? (Nikšič, 2018)

2. To choose concrete existing initiatives related to public space improvements in the locations of the partnering cities and experiment with new approaches to the participatory design of public spaces in cooperation with them. The aim was to offer a stage for new innovative ideas to be developed and tested in cooperation and dialogue, but also to critically confront the different positions between the professionals with different kinds of expertise on one side and citizens on the other. Each city defined its own approach to address the most pressing issues in the local environment.

3. To communicate and disseminate the findings of both state-of-the-art and experimentation phases to various publics (general, professional, academic, decision-makers); to incorporate the knowledge produced in learning processes within the universities in the form of masterclasses and possibly inform policymaking in the form of briefings.

To reach these goals, the experimentation phase demanded a high level of cooperation between disciplines as well as across different stakeholders, which had to cooperate in different phases of the process. The case study of each partnering city is a story in itself and provides important lessons learnt in the fields of interdisciplinarity and transdisciplinarity (Franc, Peyricot, Ermacora, \& van Hasselt, 2018). However, the detailed descriptions of them would exceed the length of this chapter; thus, it analyses the activities that took place in one of the partnering cities only. It focuses on the composition and competencies of the local partnership needed to successfully implement the project activities in Ljubljana.

\section{The Case of Ljubljana: Participatory Urban Regeneration of Large-Scale Housing Areas}

Ljubljana is the capital city of the Republic of Slovenia, which has a total population of about 2 million. The city has about 283,000 inhabitants (City of Ljubljana, 2014) and is the largest city in the country. Historically, the city used to be much smaller; the official census from 1921 recorded only 53,294 inhabitants. The rapid urban growth that started after World War II endeavoured to rebuild war-torn territories and to implement the industrialisation programme of the then existing socialist Yugoslavia (Mihelič, 2016; Rebernik, 1999). Between 1950 and 1970, the city grew quickly, with new industrial facilities and accompanying large socialist modernist housing estates. In this process, the once greenfield surroundings of the historic city were built up and the villages surrounding the historic city were swallowed up in the urbanisation process and extended through the new urban developments. In contrast to the historic urban fabric, these new developments, popularly called socialist neighbourhoods, were mainly built upon the mid- to high-density urban typologies (Čepič et al., 1997), which caused not only a huge disparity in terms of the scale between traditional and newly built structures but also some tensions between the original rural residents (who were then becoming a minority) and the newly settled more urban population. These tensions have never been completely resolved.

The main current issue of these socialist-constructed suburban areas is that they have aged but have not yet been subjected to a comprehensive regeneration programme. The built structure is in 
need of physical renewal; moreover, the social, economic and not least, the environmental issues in these ageing areas are just as burning (Sendi, 2004; Nikšič, Goršič, Mihelič, Mujkić, \& Tominc, 2013).

Due to a long period of economic downturn in Slovenia starting in 2009, the public budgets for comprehensive urban regeneration decreased considerably (Stražišar \& Strnad, 2016). This forced the local governments and their planning departments to start considering new approaches to urban regeneration. If the pre-established practice had been very much top-down, compartmentalised and run by neo-liberal ideologies where public budgets were strongly aligned to the initiatives of private developers (Ehrlich, 2012; Ferk \& Ferk, 2008; Nikšič, 2017), the economic downturn brought the awareness of a need to combine a top-down approach with bottom-up approaches involving local communities and their own resources also (Bugarič, Pličanič, \& Pirnat, 2016). This challenged the city's urban planning department to start coordinating their activities more with other departments to achieve the desired results while having fewer resources at their disposal. The decreased financial capability of the local governments and developers seemingly made participatory approaches promising, even within the neo-liberal profit-oriented model. The skills, abilities and voluntary work of the local population have been recognised as a possible source for urban redevelopment. Even if such approaches have been much criticised in some scholarly and popular discussions (Cerar, 2014; Bugarič, 2018), because they help to sustain the system on account of the voluntary work of communities, at least in the Slovenian context they helped to promote communitybased urban planning, which includes the local population in the visioning and implementation of urban development. To a limited extent, they have also raised awareness of entirely new concepts of cooperation between the authorities and the citizens, created outside developer-driven agendas (Patti \& Polyak, 2017).

It was the socio-economic context described above that the Human Cities Ljubljana project had to inhabit when starting its activities. The urban territory and its public spaces seemed to be an ideal laboratory to experiment with more participatory urbanism; firstly, as Ljubljana has a strong legacy of self-management practices from the previous socialist system (Kavčič, 1997); secondly, because it is the largest city in the country with the most complex urban issues that need to be addressed and could serve as a model to any other smaller Slovenian city or town with less complex issues if successful; thirdly, as the City of Ljubljana invested a lot of public money into the improvements of its city-centre public spaces in a top-down manner while neglecting suburban ones, thus accelerating critiques about the (un)just use of public money (Nikšič, 2014; Nikšič \& Sezer, 2017); and not least because the public space is a common space where the interests of many stakeholders meet. The main mission of Human Cities Ljubljana thus became the development of experimental approaches to participatory urban regeneration in the suburban areas of the city through the community-based redesign of public spaces in the large socialist housing blocks.

\section{Setting Up and Managing Local Experimental Activities}

The local Human Cities team in Ljubljana is based at the Urban Planning Institute of the Republic of Slovenia (UIRS), a key national research institution in the field of urban planning (www.uirs.si). The Human Cities core group at the Urban Planning Institute of the Republic of Slovenia consisted of professionals from different professional backgrounds such as architecture, geography, landscape architecture, information technology engineering and pedagogy, and had full autonomy in setting up the concrete agenda of the local project in Ljubljana. 
Being in such a position, the Urban Planning Institute of the Republic of Slovenia proposed a twofold strategy: firstly, to develop and test new participatory tools in the case study of a suburban public space; and secondly, to set up a stage for a systematic change to introduce more participatory procedures in urban (re)development practice.

Through a comprehensive review of the existing literature, daily press, internet and other sources (Nikšič, Goršič, \& Tominc, 2018), the Urban Planning Institute of the Republic of Slovenia mapped the existing civil initiatives in Ljubljana and over a wider area. The mapping was focused on the initiatives that worked either in the processes of getting the citizens involved in decision-making, or those that were making some concrete interventions in public open spaces in a participatory manner. Two aspects have been researched in detail: the ability and readiness of the mapped initiatives to try to work across different interest groups, as well as their potential to scale up their activities in the longer term (Nikšič, 2018). The final goal of this initial mapping was to invite one civil initiative to co-design and co-produce the Human Cities Ljubljana experiment in the 2014-2018 period.

The selected initiative was Skupaj na ploščad! (Skupaj na ploščad, 2016), which literally translates as “Together on the platform!” It was set up in 2013 by a group of architects and landscape architects living in one of Ljubljana's most densely populated areas in the neighbourhood of Ruski car ("Russian Tsar") on the northern outskirts of the city. This is a distinctive urban environment - one of the largest comprehensively planned socialist housing estates in Slovenia built in the 1970s to provide nearly 2,700 flats for the working class of the time (Čelik et al., 2016; Jamšek, 2016). Its core part consists of two parallel rows of blocks of flats that run east-west and connect the main public bus stop at one end with the railway station at the other end. Due to their height (15 floors), length (approx. 470 metres) and well-thought-out colour scheme, they have the appearance of a distinctive urban structure. The space between them is a lengthy street-like central open space called Bratovševa ploščad (Bratovš platform), which hosts the most basic amenities of the estate such as a local shop, a bank, a pharmacy and a community centre. It is one of the largest paved open areas in suburban Ljubljana and serves as the roof of the underground parking at the same time. A parallel linear green area is provided to the south and hosts sports and recreational facilities as well as a kindergarten and a school, while to the north two more streets run perpendicular to it and form a large park in between. Given this comprehensively planned layout and distinctive architectural outlook, the neighbourhood quickly became a popular living environment as well as a setting for the Slovenian film industry (Kučan, 2016).

Since the 1990s, when Slovenia started its transition from a planned economy to an open market economy, socio-economic changes have been ongoing, and the large socialist estates have been facing the new realities. To some extent, they have lost their attractiveness in the eyes of the citizens and entered the path of spatial and social degradation (Mihelič et al., 2005). Privatisation of the housing stock was one of the biggest issues and had many consequences, one of them being the ambiguous rights and responsibilities to use and take care of the common spaces.

Within this context, the main objective of the civil initiative Skupaj na ploščad is to address the issues of spatial degradation of the Ruski car neighbourhood in cooperation with other residents. The main aim of the group is to help to organise the locals into a common campaign to revive the central open public space of the neighbourhood and thus strengthen social ties among residents (Bastin, 2018). The initiators were aware of the connection between the physical degradation and the social issues of the neighbourhood from the beginning. They also had insight into who the active residents were who voluntarily invested time, knowledge or other personal resources into the community. 
To reinforce the sense of community that had been lost over the decades, Skupaj na ploščad organised some events in the central open space of the neighbourhood, such as an open-air film night, a communal herbal garden, community beehives, workshops with children, a market for fresh vegetables from the farms in the nearby villages, etc. (Bastin, 2018). The variety of their activities and of the publics they had managed to involve indicated the liveliness of Skupaj na plošcad; therefore, the Urban Planning Institute of the Republic of Slovenia chose it and the Ruski car neighbourhood as the experimentation case study of Human Cities Ljubljana.

One of the initial goals was to use this neighbourhood as a showcase for participatory changes in other neighbourhoods also. The Urban Planning Institute of the Republic of Slovenia invited city officials to take part in the activities from the very beginning of the experiment, so that they could have full insight into the process and thus be able to develop some relevant supportive policies alongside the process. Improving the community's financial and management capacity through supportive city policies was an important goal of the experiment. However, attempts to get the central city administration involved were unsuccessful despite much effort by the Urban Planning Institute of the Republic of Slovenia, mainly due to the well-established top-down approach to urban development (Bastin, 2018). Nevertheless, the neighbourhood-level officials from the district office (heading one of 17 territorial units as a form of the city's territorial sub-administration) responded and joined. Even though this level of city authority has no decision-making or budgetary powers, its support was important - it provided an additional communication channel with the residents, as well as making its premises available for public meetings and events.

\section{Putting the Actors into the Action}

Enabling the wider community to get involved was important to the wider experimentation goals of the project. Even if the Skupaj na ploščad networks were initially helpful to identify the active citizens, using these already established networks following Skupaj na ploščad's business-as-usual method proved to be insufficient to attract new local players. The experiment crucially needed more active residents to take the role of local experts, especially in mapping the local needs, on the one hand, and bottom-up resources to support the development of appropriate responses to these needs, on the other. Communication, leadership and management questions to successfully kick off the experiment arose all at once. At that point, good cooperation between an institution (the Urban Planning Institute of the Republic of Slovenia) with good theoretical insights into the prerequisites for a successful participatory process and a locally existing civil initiative (Skupaj na ploščad) with established contacts within the neighbourhood was key for success. While the role of the Urban Planning Institute of the Republic of Slovenia was mainly methodological, Skupaj na ploščad's contribution was in promoting the events through locally established channels to attract as many residents as possible. Their cooperation succeeded in bringing relevant local actors to the same table in a meaningful way.

The Urban Planning Institute of the Republic of Slovenia and Skupaj na ploščad developed a set of events where residents could express their opinions on how participatory processes should be set up and undertaken. The first event took place in spring 2016, when a so-called neighbours' walk was organised (Figure II.9.1 and Figure II.9.2). The idea was to invite the residents to take the role as the guides of the walk and thus reveal the assets and issues of the neighbourhood through their own eyes. Some residents joined and pointed out many crucial issues to be tackled in the regeneration efforts. However, it turned out that few people would attend such an event, even if it was announced in the 


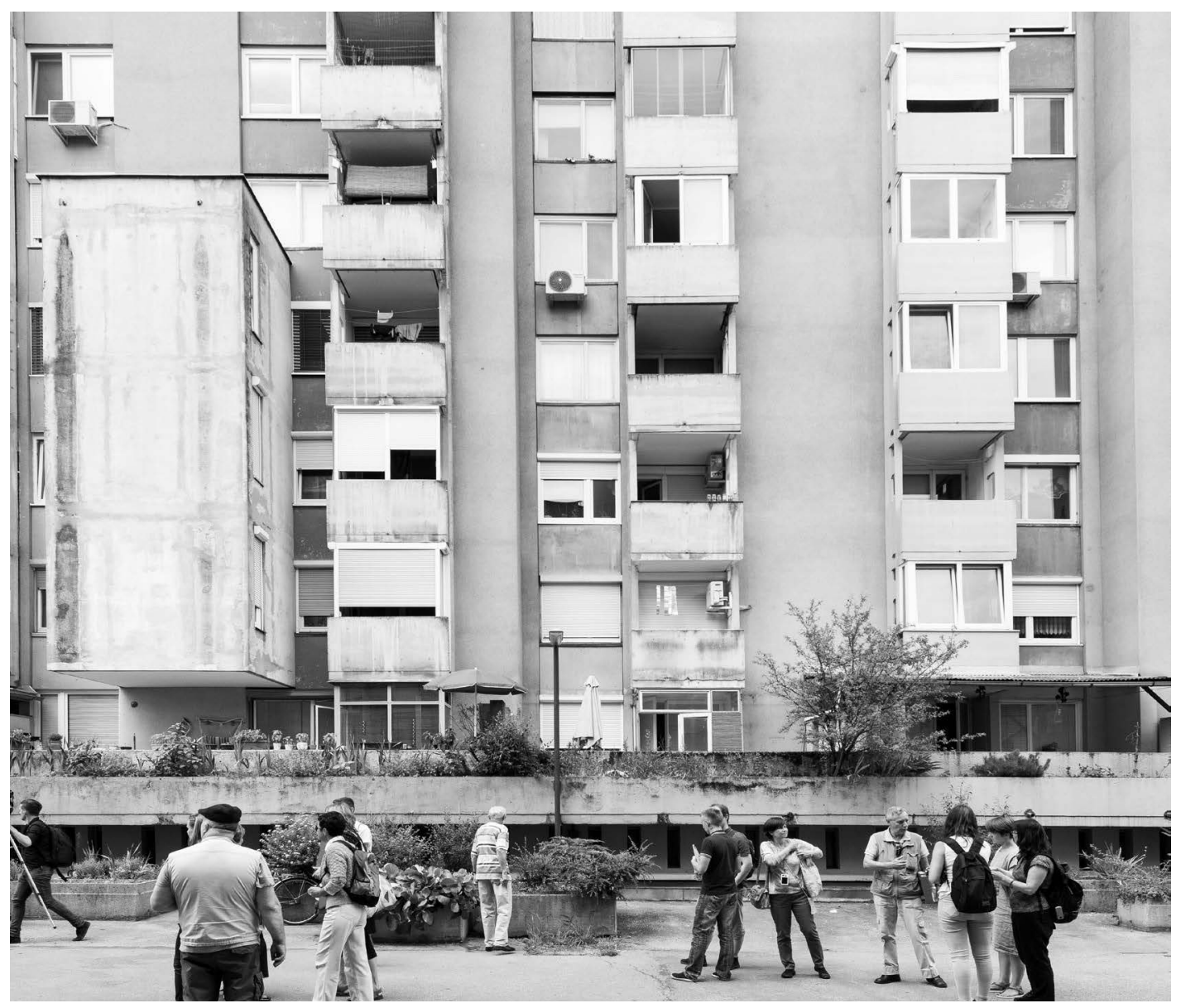

FIGURE II.9.2 Ruski car neighbourhood is one of the most densely built-up areas in Ljubljana, it was constructed in the 1970s and needs a comprehensive regeneration. Photo by Blaž Jamšek/UIRS photo archive Human Cities Ljubljana.

manner that Skupaj na ploščad would normally use. The same kind of low attendance happened at the next event, a round table discussion, which took place under the moderation of the Urban Planning Institute of the Republic of Slovenia in the city's district office. More or less the same residents took part and once more mainly talked about the problems that seemed to be ongoing for a long time and could not be resolved by their own activities.

The focused discussion offered further insights into the problems and potentials of the neighbourhood. The problems were mainly related to bad maintenance of common spaces, ageing infrastructure such as leaking gas and water pipes and, above all, the clear absence of interest of the central city authority to address the issues together with the residents. At the same time, the residents were not able to list that many potentials. It also became clear that they expected that the Urban Planning Institute of the Republic of Slovenia, as a national urban planning institution, could help things move further. This was an important input for the Urban Planning Institute of the Republic of Slovenia 


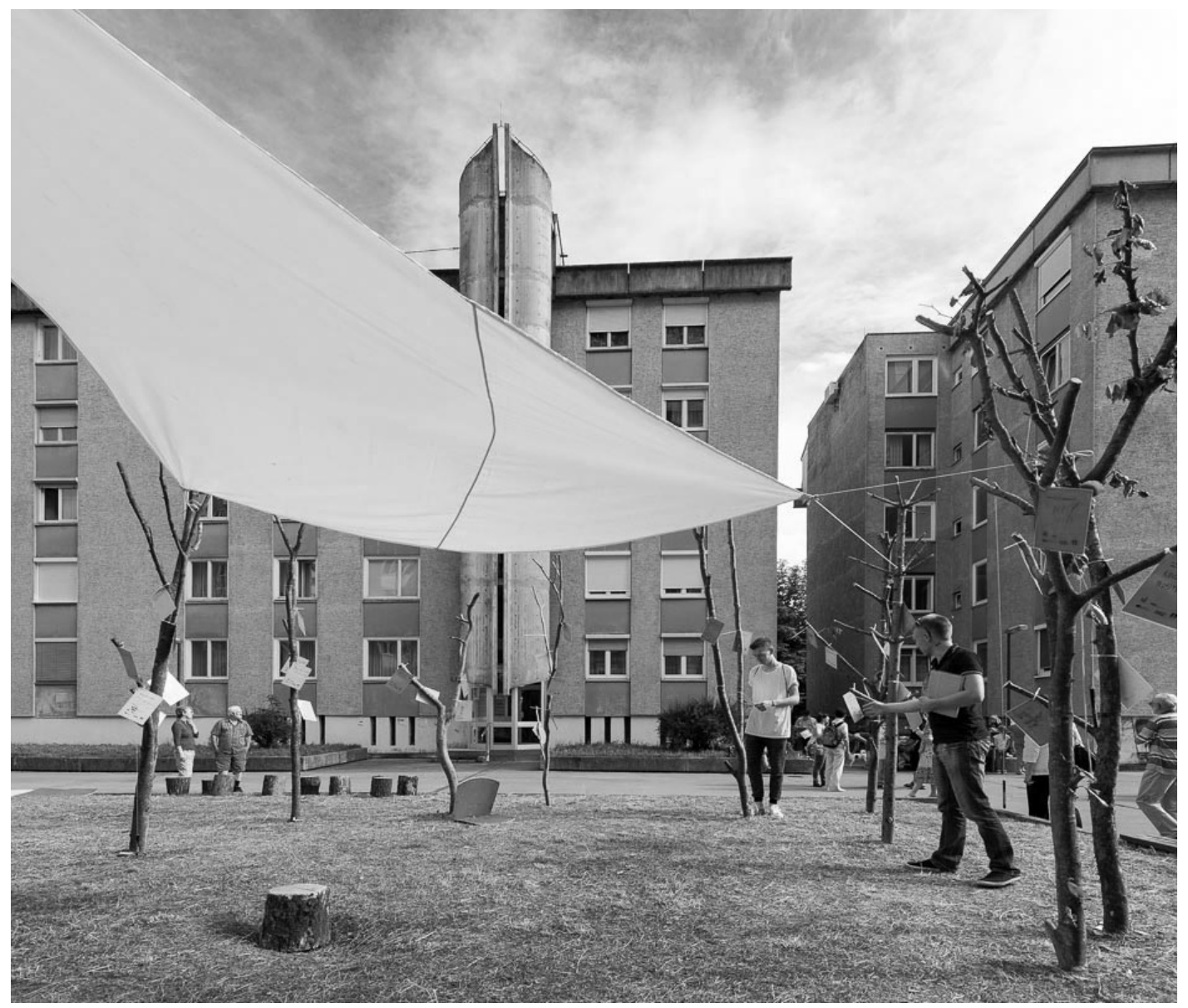

FIGURE II.9.3 The public picnic was a participatory experiment - along with the sociable activities various empirical data on the place were gathered based on a transdisciplinary approach. Photo by Blaž Jamšek / UIRS photo archive Human Cities Ljubljana.

as a main facilitator of the experimentation process, as it showed a gap between the inhabitants' expectations and the institution's abilities and powers in decision-making. Unfortunately, the Urban Planning Institute of the Republic of Slovenia was not in a position to solve concrete problems that were in the jurisdiction of the city's central authority; even less so as it did not manage to establish cooperation with this authority.

When the reasons for the low levels of attendance by residents were analysed after the first two public events (the neighbours' walk and the round table discussion), it became clear that the presence of the Urban Planning Institute of the Republic of Slovenia, which on the one hand was a trigger for the residents already active to attend, while putting many people's hopes on the institution's assumed influence in the city's decision-making, was at the same time a discouragement for the rest of the residents due to the Urban Planning Institute of the Republic of Slovenia's reputation as just one more institution alienated from real life. Therefore, new approaches had to be developed to invite new residents to join. As a result, the action plan was reworked. Instead of following a rather profes- 
sionally driven agenda, the new approach focused on socialisation activities while still including the professional agendas in the background. A big public picnic was organised in early summer 2016 in the central public space of the neighbourhood (Figure II.9.3). It was mainly advertised through the Skupaj na ploščad social media, posters in public spaces and on the information boards of the blocks of flats, as well as through the district office's communication channels.

This social event was organised around local food, socialising and street games. Local food producers from the villages bordering the neighbourhood were invited to prepare the food to get them involved in the process of rethinking the neighbourhood's and district's future and to diminish the gap between the urban and rural inhabitants. Skupaj na ploščad, in cooperation with the Urban Planning Institute of the Republic of Slovenia, organised some street games on the same day, and the team from the Urban Planning Institute of the Republic of Slovenia brought some research tools also: a large model on which residents pinned their ideas was established, and wish-trees with write-on-me leaves were planted to collect residents' visions of the future neighbourhood. Short video interviews were taped among the participants with the same aim of collecting ideas. Around 150 residents attended the event, a big relief for the organisers who were keen to make contact with a new group of residents outside the already established group of active residents. The event also revealed the importance of including different enablers in the planning of public events - it was the cooperation with locally based actors (Skupaj na ploščad, local producers of food, the district office, etc.) that enabled the Urban Planning Institute of the Republic of Slovenia, as the main manager of the Human Cities experiment, to succeed in addressing a wider group of residents.

Many ideas were collected by the residents through different side activities that took place alongside the event. They helped Skupaj na ploščad to understand the desires of residents better. These insights later informed the urban design concept for the redesign of the central public space. However, the Urban Planning Institute of the Republic of Slovenia, in its endeavour to develop and test new participatory tools, was not ready to finish these activities just yet. The data gathered during the picnic showed that mainly families with children were attracted to the picnic. On the other hand, the event revealed that some residents would not come out of their flats due to their lifestyles, characterised by spending their spare time inside their flats rather than in socialising in the open spaces of the neighbourhood. Through the interviews, the organisers learnt that one of the main reasons for people staying indoors was their attachment to the TV and computer screens. This observation presented a new challenge to the Human Cities Ljubljana experiment.

\section{Addressing the Focus Groups Through a Tailored Approach Developed by an Interdisciplinary Team of Experts}

The interdisciplinarity of the Urban Planning Institute of the Republic of Slovenia's own team proved to be crucial to be able to address two specific groups (information technology-oriented residents and youngsters) further. Having an information technology engineering expert in the team enabled the Urban Planning Institute of the Republic of Slovenia to realistically plan the development of an online application that would enable residents who did not wish to or did not have the courage to attend public meetings to express their points of view about the neighbourhood. The Human Cities Ljubljana core group prepared a brief stating the main problem (the lack of participation of the "digitalised" part of the local population) and the possible solution (development of a new information technology-based tool). The information technology engineer, with a lot of working experience in urban planning, proposed sensible technical options to address the issue; thus, 
communication with other experts in the core group proceeded quite quickly and smoothly. Within a short period of time, a new digital tool called "A Photostory of Our Neighbourhood" (PON) was set up. It was an online application that invited residents to look at their living environments through photography (Nikšič, Tominc, \& Goršič, 2018). By submitting photos and their captions, residents were expressing their notions on different aspects of living in the densely populated living environments. Once again, similarly to the neighbours' walk, the residents were put in the role of local experts. To keep the Photostory of Our Neighbourhood structured along the lines of urban planning objectives, it was structured into five different categories: most pleasant place in my neighbourhood; professions in my neighbourhood; my neighbour; boundaries of my neighbourhood; shared values in my neighbourhood. Over 170 entries were received by the call for photos, which was open for 45 days and mainly advertised through social media. The collection of the photos was advertised as a proper photography competition with prizes for the best entries, while the broader aim within the Human Cities experiment was clearly explained. Organising the event as a photography competition also demanded a professional jury. Thanks to the European scale of Human Cities, the Urban Planning Institute of the Republic of Slovenia was able to set up such a jury at international level, which raised the relevance of the competition in the eyes of residents considerably. International jury members affiliated to the fields of photography and design were named in cooperation with other European Human Cities partners, and they greatly improved the local visibility of the project.

Another focus group identified at the Ruski car picnic were the children. The picnic showed that extended families (including parents, grandparents and other relatives) would more likely join the participatory activities if children were involved. Getting children involved in the participatory processes thus became an important goal. However, developing a tool to address the young population as active citizens proved to be a demanding issue. Even if the Urban Planning Institute of the Republic of Slovenia had a pedagogic expert within its core team, practical experiences of working with children would be needed more than excellence in theoretical and research approaches. Therefore, the Urban Planning Institute of the Republic of Slovenia decided to bring into collaboration another institution that had a long record of workshops implemented with schoolchildren. The cooperation between the experts of the Urban Planning Institute of the Republic of Slovenia who gave guidelines in terms of the contents to be communicated to the children, and the Museum of Architecture and Design, who gave advice about the appropriate educational tools to be used, resulted in a new sevensession learning programme for pupils. It was well adjusted to the needs of the concrete community at Ruski car, as Skupaj na ploščad took part in the development of the tool also. It was built around the skills of active citizenship, empowering children to become active citizens and enabling them to contribute to a betterment of their living environments through their own activities. The sessions were a combination of lectures, analytical walks around the neighbourhood and hands-on sessions. The contents of each of the sessions was developed in detail and sometimes required that further professionals become involved (Figure II.9.4). For example, in the session addressing photography as a research method, the children got in contact with a professional photographer who explained the basics of analytical photography and joined in the hands-on session with the children. Similarly, an architect joined in when the children were discovering the art of making street furniture from recycled materials. All the cooperating professionals coordinated their activities into a coherent whole through the Urban Planning Institute of the Republic of Slovenia as the main facilitator of the process. On the other hand, Skupaj na ploščad played a crucial role in accommodating children's Human Cities activities with their regular obligations in school, as they had pre-established strong relations with the teachers of the local school. 


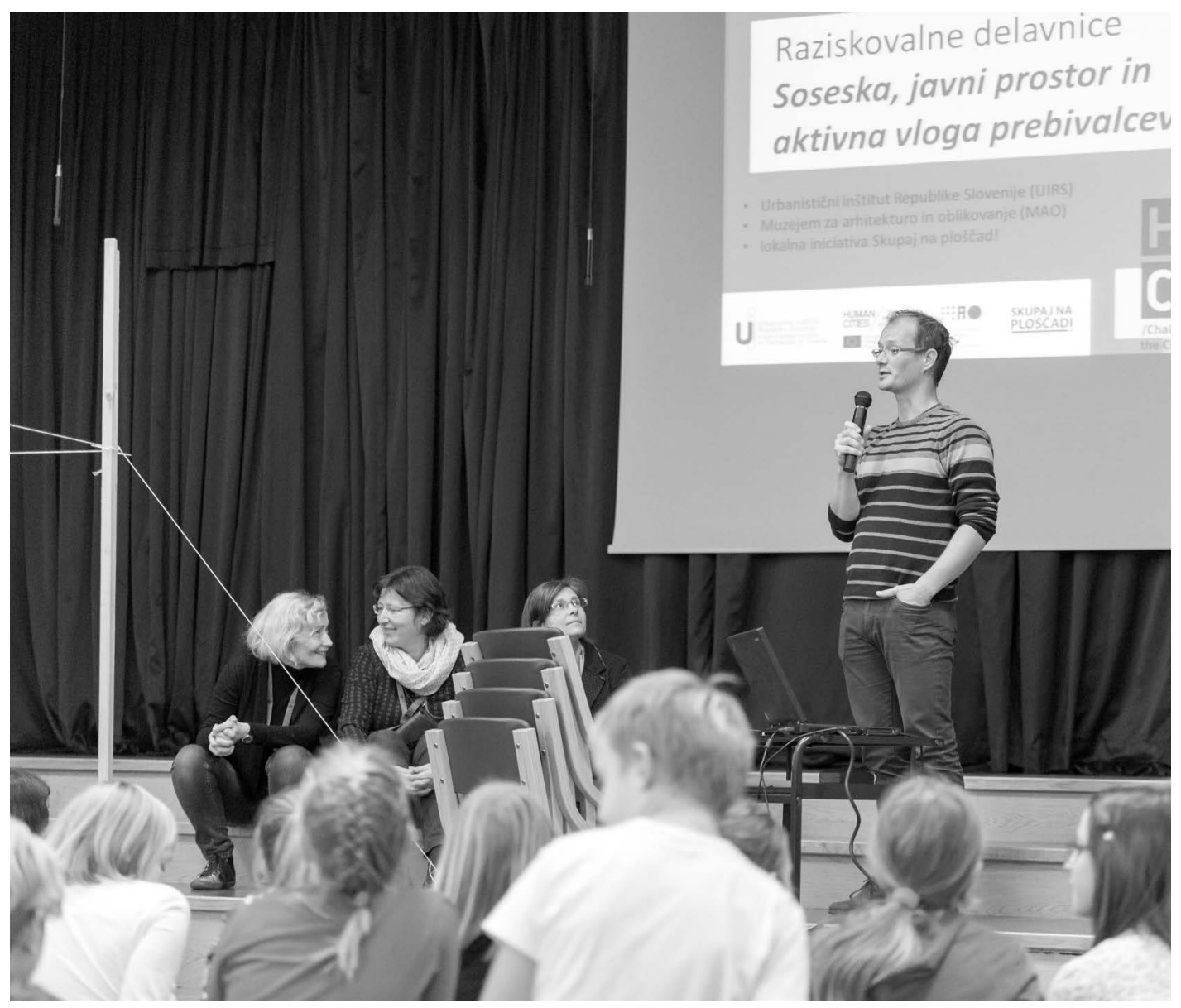

FIGURE II.9.4 Professionals of different backgrounds and school teachers joined their forces to set up the educational module on active citizenship. Photo by Blaž Jamšek / UIRS photo archive Human Cities Ljubljana.

Some of the children's tasks had to be done at home in the form of a piece of homework with the whole family. This gradually increased the number of interested people in the neighbourhood. When, in summer 2017, another public event was organised in the neighbourhood in cooperation with the Department of urban planning of the Faculty of architecture in Ljubljana and in the presence of international Human Cities partners, the attendance rate of the residents was considerably higher. In organisational terms it demanded the cooperation of many partners again as many activities were going on as a part of the programme, such as participatory street furniture making (Figure II.9.5), urban gardening workshops, photography and sketching sessions, street exhibitions, etc. The hands-on workshop activities were an excellent opportunity for direct exchanges between local inhabitants and the international team of experts for common benefits. 


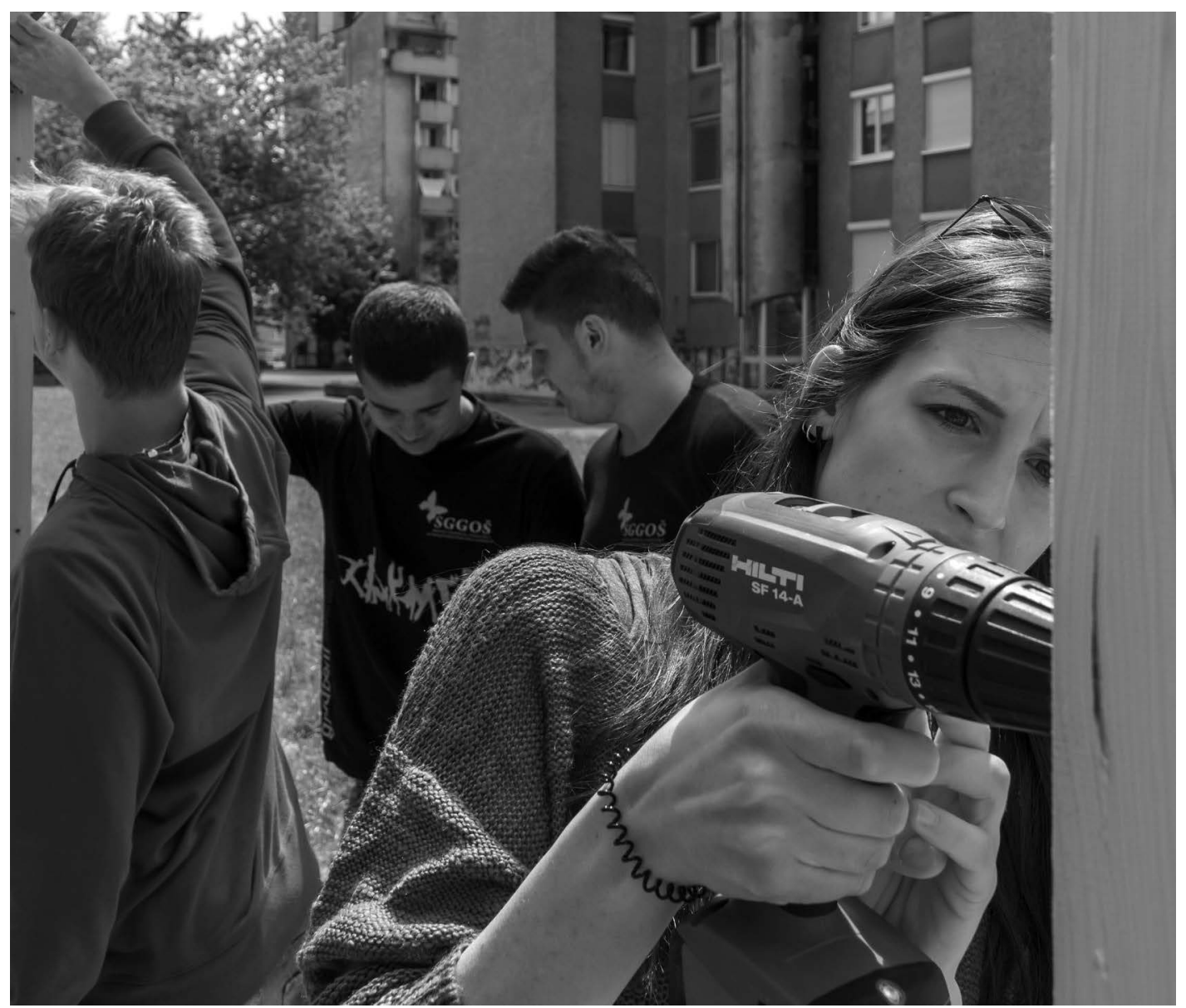

FIGURE II.9.5 Some residents may not be technically skilled enough to produce street furniture but can learn the skills during the hands-on exchanges with the experts. Photo by Tomaž Zupan / UIRS photo archive Human Cities Ljubljana.

\section{The Importance of a Strong Leadership Moving Towards a Common Goal}

Human Cities activities in Ljubljana are an example of an experimental approach to urban regeneration processes based on participatory principles, while strongly supported by the institutional framework. They show how important cooperation between different institutions, and professionals with different types of expertise are for the setting up of participatory urban design practice in a context that traditionally lacked such approaches. They also show how interinstitutional cooperation between local and international institutions can develop new approaches that are innovative while tailored to the specific needs of a concrete socio-spatial context.

Such cooperation needs strong leadership - an institution or organisation that can invite appropriate partners into the process and coordinate their activities towards the common goals. One of the requirements for the success of such an approach is the ability of the lead partner to indicate appropriate additional partners and listen to the suggestions coming from each of them. The lead partner thus 
does not act as a client that orders the required services from different suppliers, but is in the role of an agent setting up a network of partners that will jointly seek the best solutions to the given issues. The lead partner's ability to work on the basis of the equality of the partners while having a strong strategy as well as the operational tools to successfully coordinate activities proved to be an important element for success. In doing so, the lead partner cannot always tackle all the issues itself and also needs the skill to pass its authority to other partners within the commonly agreed strategies (as in the example of Skupaj na ploščad's full coordination with the teaching staff of the primary school). This ability of a lead partner becomes even more crucial with the increase in size and complexity of a project and partnership.

In the case of the Urban Planning Institute of the Republic of Slovenia acting as the main facilitator of the process, there were several fortunate advantages. Firstly, its own interdisciplinary structure made it able to act in a cross-disciplinary way and thus understand the value of different professions working together. Secondly, its position as an independent national research and advisory body allowed it to act as a decision-maker of the project, which was fully independent from the interests of daily politics and the agendas of any groups with interests (e.g. capital-driven investors). Thirdly, its embeddedness in the international professional community (while not having strict and detailed international guidance imposed, but rather given the freedom to set up its own locally embedded guidance) enabled it to involve independent experts from abroad with specific knowledge when needed and thus enlarge its operational capacity. Additionally, its relative financial independence (50\% of the project activities were provided by the European Union Creative Europe programme) gave it more of a manoeuvring space compared with situations when it had to finance all the activities by itself.

The resources that were available to the Urban Planning Institute of the Republic of Slovenia outside the core team were crucial in developing its capacity to develop an innovative approach, as it could not cover all tasks as well as costs by itself. This also explains the failures in the process - due to the lack of contact with the central city authorities, the activities have not developed into something more than a mere experiment to date. This means that the final goal has not been achieved yet: the change to the previously established urban planning practices towards more participatory ones has not yet started, and making them part of the urban planning system remains an ongoing endeavour. This shows how peculiar the results of the otherwise well-thought-out processes can be, if only small (however important) steps in the processes do not go according to plan and no alternative solutions are sought or available. In the case of Human Cities Ljubljana, this has largely remained a lost opportunity. Or, if we put it differently, a lesson learnt that inevitably demands further action regarding the institution's capacity building.

The presented case also shows the appropriateness of the experiment as a tool to test the ability of partners (in Ljubljana's case, these also importantly include residents) to act together. Experimentation is open ended and allows failures, which encourages actors to join more easily. At the same time, the open-endedness demands more flexibility of all the actors. As Human Cities Ljubljana showed, this issue can at least in part be solved by the inclusion of various experts throughout the process. Human Cities Ljubljana was privileged in these terms, as it had professional capacity at both local and international levels at its disposal, as well as some financial resources to afford it. These are the conditions to be ensured when experimentation in a multi- and transdisciplinary manner is chosen as the core approach to the initiation of structural changes within already established practices.

Any experimentation process is open ended by definition, which demands that many experts take part in the process to fill in the gaps in a flexible manner. This makes interdisciplinary and trans- 
disciplinary approaches so crucial for the success of such a project. Nevertheless, in order to make the whole process fruitful, perhaps the most important element is strong leadership combined with vision and operational strategy to drive the project towards worthwhile and sustained successes. In the case of Ruski car, these include strengthened ties among local residents, empowered local civil initiative Skupaj na ploščad and new street furniture and open space arrangements, which serve as new gathering places for the local community. The Human Cities activities are continuing in 2020-2024 period and can be followed at www.humancities.eu.

\section{Acknowledgements}

The author acknowledges financial support from the Slovenian Research Agency (research core funding No. P5-0100) and the European Union's Creative Europe/Culture programme.

\section{References}

Bastin, C. (2018). Interview with Damjana Zaviršek, the initiator of the Skupaj na ploščad! initiative in the Ruski car neighbourhood, Ljubljana. Not published. Human Cities archives of the Urban Planning Institute of the Republic of Slovenia.

Bugarič, B. (2018). Urban acupuncture treatment: Implementing communication tools with youth in Ljubljana suburbs. Urban Challenge, 29, Supplement, 95-108.

Bugarič, B., Pličanič, S., Pirnat, R., et al. (2016). Analiza možnosti za izvajanje urbanih projektov z uporabo javno zasebnega partnerstva. Ljubljana: Urbanistični inštitut Republike Slovenije, Pravna fakulteta, Fakulteta za arhitekturo.

Čelik, M., Skansi, L., Kukoč, V., Malešič, M., Sapač, E., \& Zupančič, B. (2016). Streets and neighbourhoods: Vladimir Braco Mušič and large scale architecture. Ljubljana: Museum of architecture and design.

Čepič, T., Ferle, M., Horvat, M., Mihevc, B., Mušič, V.B., Plesničar-Gec, L., Sivec, I., Šinkovec, I., Šumi, N., Vičič, B., Zalar, F., \& Žmuc, I. (1997). Settlement of the Ljubljana basin: Urban development of Ljubljana. Ljubljana: Municipal Museum of Ljubljana.

Cerar, A. (2014). Od odziva do pobude: Potencial kontributivne participacije/From reaction to initiative: Potentials of contributive participation. Urban Challenge, 25(1), 24-36, 93-106.

City of Ljubljana (2014). Ljubljana glavno mesto/Ljubljana capital city. Ljubljana: Mestna občina Ljubljana/ City Municipality of Ljubljana.

Coirier, L., Goličnik Marušić, B., \& Nikšič, M. (Eds.). (2010). Human Cities: Celebrating public space. Brussels: Stichting Kunstboek.

Ehrlich, K. (2012). Conflicting visions of urban regeneration in a new political and economic order: The example of the former bicycle factory ROG in Ljubljana, Slovenia. Anthropological Journal of European Cultures, 21(2), 68-88.

Ferk, B., \& Ferk, P. (2008). Public-private partnership in Slovenia: An analysis of the first successful projects of public-private partnership in Slovenia. European Public Private Partnership Law Review, 4, 175-184.

Franc, J., Peyricot, O., Ermacora, T., \& van Hasselt, F. (Eds.). (2018). Human cities challenging the city scale: Journeys in people-centred design. Basel: Birkhäuser Verlag.

Houlstan-Hasaerts, R., Tominc, B., Nikšič, M., \& Goličnik Marušić, B. (Eds.). (2012). Reclaiming public space: Cross perspectives based on research. Ljubljana: Urban Planning Institute of the Republic of Slovenia.

Jamšek, B. (2016). Prenova Bratovševe ploščadi/Renovation of Bratovševa platform. Bachelor degree thesis. Ljubljana: University of Ljubljana, Faculty of Architecture.

Kavčič, B. (1997). Slovenia: From self-management to co-determination. In: Markey, R., \& Monat, J. (Eds.). Innovation and employee participation through works councils: International case studies. Aldershot: Avebury.

Kučan, A. (2016). Sreča na vrvici/Luck on a string. Mladina, (38). Retrieved 09 December 2018 from https:// www.mladina.si/176490/sreca-na-vrvici/. 
Mihelič, B. (Ed.). (2016). Potret mesta: Ljubljana/Portrait of the city: Ljubljana. Ljubljana: City Municipality of Ljubljana.

Mihelič, B., Bizjak, I., Goršič, N., Tominc, B., Buzar, S., Phillips, O. M., Hall, R., Haase, A., Kabisch, S., \& Steinfuhrer, A. (2005). Re urban mobil: Mobilising re-urbanisation on condition of demographic change. Leipzig: UFZ Centre for Environmental Research.

Nikšič, M. (2014). Access to quality open public space as an urban sustainability measure. In: Bokor, L., Munkacsy, B., \& Niksic. M. (Eds.). Locality and (un)sustainable settlements, 284-303. Shrewsbury: Frugeo Geography Research Initiative.

Nikšič, M. (2017). Is a walkable place a just place? The case of Ljubljana. Built Environment, 43(2), 214-235.

Nikšič, M. (2018). Civil initiatives improving urban public spaces. In: Nikšič, M., Goršič, N., Tominc, B., Selloni, D., Galluzzo, L., Fassi, D., Peyricot, O., \& Daeron, I. Human Cities: Challenging the city scale 2014-2018: Investigation, 131-141. Saint-Etienne, France: Cite du Design.

Nikšič, M., Goršič, N., Mihelič, B., Mujkić, S., \& Tominc, B. (2013). Litostroj neighbourhood: Guidelines for maintenance and renewal of distinctive areas of the city of Ljubljana. Ljubljana: Urban Planning Institute of the Republic of Slovenia.

Nikšič, M., Goršič, N., \& Tominc, B. (2018). Tools for participatory provision of urban public spaces: Human Cities experience. In: Nikšič, M., Goršič, N., Tominc, B., Selloni, D., Galluzzo, L., Fassi, D., Peyricot, O., \& Daeron, I. Human Cities: Challenging the city scale 2014-2018: Investigation, 7-23. Saint-Etienne, France: Cite du Design.

Nikšič, M., \& Sezer, C. (2017). Public space and urban justice. Built Environment, 43(2), 165-172.

Nikšič, M., Tominc, B., \& Goršič, N. (2018). Revealing residents' shared values through crowdsourced photography: Experimental approach in participatory urban regeneration. Urban Challenge, 29, Supplement, 29-42. doi: 10.5379/urbani izziv-en-2018-29-supplement-002.

Patti, D., \& Polyak, L. (Eds.). (2017). Funding the cooperative city. Vienna: Cooperative City Books.

Rebernik, D. (1999). Population development in Ljubljana after 1945. Geographical Bulletin, 71, 41-60.

Sendi, R. (2004). Prenova stanovanjskih sosesk v Ljubljani/The renewal of housing estates in Ljubljana. Ljubljana: Urbanistični inštitut Republike Slovenije/Urban Planning Institute of the Republic of Slovenia.

Skupaj na ploščad (2016, May 5). Humana mesta. Message posted to https://www.facebook.com/ skupajnaploscad/.

Stražišar, N., \& Strnad, B. (2016). National accounts on the economic crisis in Slovenia. Ljubljana: Statistical Office of the Republic of Slovenia. 